胆石症に和ける血中および胆管内胆汁中の胆汁酸について 一特に胆道系炎症と胆汁酸に関する研究一

\author{
名古屋市立大学第 1 外科 \\ 花井 拓美 由良 二郎 品川 長夫 \\ 三宅 孝 宮池 英夫 \\ MEASUREMENT OF BILE ACIDS IN SERUM AND BILE DUCT \\ BILE IN CHOLELITHIASIS \\ - WITH SPECIAL REFERENCE TO THE RELATIONSHIP BETWEEN BILE \\ ACIDS AND INFLAMMATORY BILIARY DISEASES- \\ Takumi HANAI, Jiro YURA, Nagao SHINAGAWA, \\ Takashi MIYAKE and Hideo MIYAIKE
}

The lst Department of Surgery, Nagoya City University Medical School

胆石症46例につき従来，報告が汪とんどみられない血中および胆管内胆汁酸を測定し，とくに胆道 系炎症症例との関俰を中心に検討した。胆汁酸の測定には $3 \boldsymbol{\alpha}-\mathrm{HSD}$ 固定化酵素を組み合せた高速液体 クロマトグラフィーを使用した。成績および結論：(1) 胆のう結石症例では, ビ系石に比べュ系石症例 で胆管内胆汁中の TCDCA が低下していた。 (2) 胆汁の流出障害が無ければ胆汁中細菌が胆汁酸組成 に及济す影響は少ないと考えられた。 (3) 胆管炎を併発した総胆管結石症例では血中 GCDCA の上昇, 胆管内胆汁中の GCA, GCDCA, GUDCA, TUDCA の低下がみられ肝障害にともならグリシン抱合型 一次胆汁酸の排泄障害, 肝における UDCA 合成抑制, 肝に括ける器質的破䋎の可能性が示唆された。

策引用語：胆石症, 胆管炎, HPLC, 血中抱合胆汁酸, 胆汁中抱合胆汁酸

はじめに

胆石症と胆汁酸との関係は Admirand と Small の 報告1)をばめ多くの報告がみられるが，そのほとん ぞが胆石症と胆のう胆汁中胆汁酸との関係が検討され ている。 また胆汁酸の測定は従来からガスクロマトグ ラフィーが広く使用され, 最も高感度かつ信頼性に富 む方法とされてきたが，操作が煩雑であり血液などの 䭪胆汁酸を測定するには多量の試料を必要とした。 近年, 普及しつつある高速液体クロマトグラフィー （以下 HPLC と略す）は極性化合物をそのままの形で 測定できるため胆汁酸測定に適している23)とされて いる.われわれは固定化醭素を租み合わせた HPLCを 使用し, 従来, 胆石症例に招いて報告が数少ない血中

$<1984$ 年 7 月11日受理 >別刷請求先：花井 拓美 T467 名古屋市瑞穂区瑞穂町字川澄 1 名古屋市立 大学医学部第 1 外科
および胆管胆汁中の胆汁酸を測定し, 胆石, 胆汁中細 菌, 胆道系炎症と胆汁酸との関係につき検討した。

対象およU゙方法

昭和56年10月から昭和58年 1 月までの当教室におけ る胆石症例のうち血中胆汁酸, 総胆管胆汁中の胆汁酸 を同時に測定したコレステロール系結石（混合石，混 成石を含む) 症例招よびビリルビンカルシュウム結石 症例のみの 46 症例について本研究を行った，結石の同 定は結石の外観, 割面の性状および赤外線スペクトル 分析によった．血液预よび胆汁採取は手術当日に行っ た。すなわち血液は手術直前に EDTA-2Na の採血管 で採血し, 総胆管胆汁は術中に血液, 胆の5胆汁の混 入無きようにすみやかに隇菌試験管に採取した。検体 はー80号の deep freezer に保存し胆汁酸を測定した。

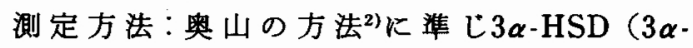
Hydroxysteroid dehydrogenase) 固定化酵素カラムを 
使用した HPLCで分析を行った，

測定䏣汁酸はウルソデオキシコール酸 (UDCA), コール酸 (CA), ケノギオキシコール酸 (CDCA), デ オキシュール酸 (DCA),リトコール酸 (LCA)の 5 種 類の胆汁酸でそれぞれにつき遊離型，グリシン抱合型， タウリン抱合型として検出した。

\section{成 緒}

胆のう炎と胆汁酸

胆のら結石症例について胆のら资症例（急性胆のう 炎, 慢性胆のう炎を示す) と非炎症例とに群別し抱合 胆汁酸值 (グリシン抱合を $\mathrm{G}$, タゥリン抱合を $\mathrm{T}$ とす る）につき検討した，胆のう炎は各種，臨床所見にも とづいて判定した。

a) 胆の5炎と血中抱合胆汁酸（図 1)

胆の5资症例 4 例, 非炎症胆の5結石症例32例につ き各胆汁酸値を比較すると，图１のごとくである. GUDCA は非炎症例 $1.86 \pm 1.67 \mu \mathrm{mol} / l$, 炎症例 $2.06 \pm$ $2.08 \mu \mathrm{mol} / l$, 以下同様飞 GCA, $4.19 \pm 7.95 \mu \mathrm{mol} / l$, $1.53 \pm 1.79 \mu \mathrm{mol} / l$, GCDA $3.52 \pm 5.03 \mu \mathrm{mol} / l$, $3.47 \pm 2.01 \mu \mathrm{mol} / l$, GDCA $0.61 \pm 1.21 \mu \mathrm{mol} / l$, $0.73 \pm 0.95 \mu \mathrm{mol} / l$, GLCA $0 \mu \mathrm{mol} / l, 0 \mu \mathrm{mol} / l$, TUDCA $\quad 0.07 \pm 0.14 \mu \mathrm{mol} / l, \quad 0.56 \pm 1.12 \mu \mathrm{mol} / l$, TCA $0.8 \pm 2.0 \mu \mathrm{mol} / l, 0.88 \pm 1.01 \mu \mathrm{mol} / l$, TCDCA $0.8 \pm 1.74 \mu \mathrm{mol} / l, 2.19 \pm 3.03 \mu \mathrm{mol} / l$, TDCA $0.29 \pm$ $1.54 \mu \mathrm{mol} / l, 0 \mu \mathrm{mol} / l$, TLCA $0 \mu \mathrm{mol} / l, 0 \mu \mathrm{mol} / l$ で あった。各胆汁酸值において群間に有意差を認めな かった.

b) 胆のう炎之胆管胆汁中抱合胆汁酸（図 2)

胆のう炎症例 5 例，非炎症性の胆のう結石症例29例 につき胆管内胆汁中の抱合胆汁酸濃度を測定した。 GUDCA 非炎症 $796.3 \pm 763.22 \mu \mathrm{mol} / l$, 炎症例

図 1 胆のう結石症における血中抱合胆汁酸

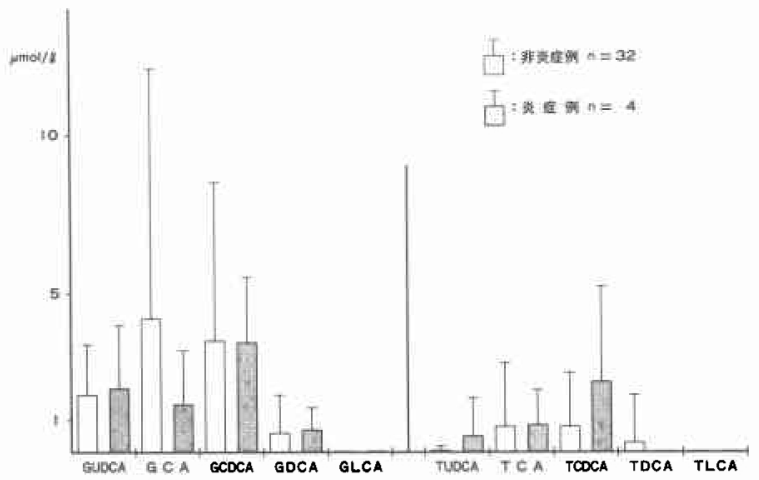

図 2 胆のう結石症における胆管内胆汁中抱合胆汁酸

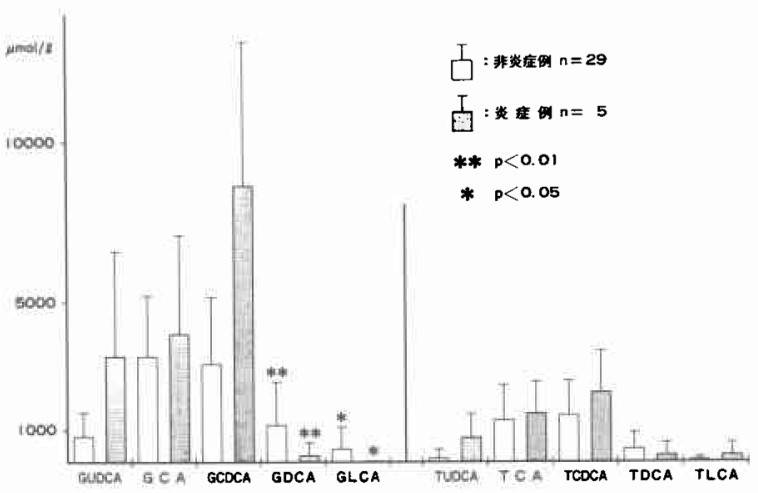

$3,345.12 \pm 3,345.14 \mu \mathrm{mol} / l$, 同様に GCA 3,290.26士 $2,205.61 \mu \mathrm{mol} / l, 4,088.92 \pm 318.18 \mu \mathrm{mol} / l, \mathrm{GCDCA}$ $3,080.85 \pm 2,151.34 \mu \mathrm{mol} / l, \quad 8,596.41 \pm 4,504.34$ $\mu \mathrm{mol} / l$, GDCA $1,176.39 \pm 1,289.58 \mu \mathrm{mol} / l$, $208.02 \pm 453.5 \mu \mathrm{mol} / l$, GLCA $34.71 \pm 85.36 \mu \mathrm{mol} / l$, $0 \mu \mathrm{mol} / l$, TUDCA $186.25 \pm 210.36 \mu \mathrm{mol} / l, 786.53 \pm$ $627.52 \mu \mathrm{mol} / l$, TCA $1,359.32 \pm 1,056.17 \mu \mathrm{mol} / l$, $1,483.73 \pm 972.12 \mu \mathrm{mol} / l$, TCDCA $1,470.18 \pm$ $1,123.07 \mu \mathrm{mol} / l, 2,161.96 \pm 1,236.67 \mu \mathrm{mol} / l$, TDCA $371.14 \pm 474.95 \mu \mathrm{mol} / l, \quad 187.17 \pm 408.06 \mu \mathrm{mol} / l$, TLCA $20.75 \pm 41.26 \mu \mathrm{mol} / l, 193.40 \pm 421.57 \mu \mathrm{mol} / l$ であった，GDCA，GLCA において资症群は非炎症群 に比較し有意に（それぞれ $\mathrm{p}<0.01, \mathrm{p}<0.05 ）$ 低值と なった。 その他の胆汁酸分画においては群間に有意差 を認めない。

胆管炎と胆汁酸

胆管炎ともっとも関係の深い総胆管結石症例につい て胆管炎併発症例とそうでない症例に群別（血中およ び胆管内胆汁中の抱合胆汁酸濃度につき比較検討し た。胆管炎症例とは Charcot の 3 徵を呈した急性胆管 资症例で術前に保存的療法で臨床的に治癒している症 例を示す。

a) 胆管炎々血中抱合胆汁酸（図 3)

GUDCA は非炎症例 $1.16 \pm 1.56 \mu \mathrm{mol} / l$ に対し资症 例 $2.98 \pm 5.08 \mu \mathrm{mol} / l$, 同様に GCA は $4 \pm 5.48 \mu \mathrm{mol} / l$, $40.9 \pm 40.92 \mu \mathrm{mol} / l$, GCDCA は $4.43 \pm 4.83 \mu \mathrm{mol} / l$, $26.93 \pm 23.41 \mu \mathrm{mol} / l$, GDCA は $0.80 \pm 0.73 \mu \mathrm{mol} / l$, $0.71 \pm 0.71 \mu \mathrm{mol} / l$, GLCA は trace, trace, TUDCA は0.08 $\pm 0.2 \mu \mathrm{mol} / l, 0.64 \pm 1.1 \mu \mathrm{mol} / l$, TCA は $0.52 \pm 0.76 \mu \mathrm{mol} / l, 27.75 \pm 37.51 \mu \mathrm{mol} / l$, TCDA は $1.08 \pm 1.28 \mu \mathrm{mol} / l, 20.88 \pm 26.39 \mu \mathrm{mol} / l$, TDCA は 
図 3 総胆管結石症における血中抱合胆汁酸

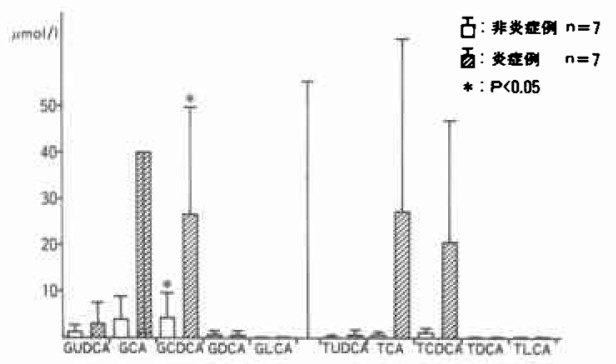

$0.08 \pm 0.12 \mu \mathrm{mol} / l, \quad 0.08 \pm 0.16 \mu \mathrm{mol} / l, \quad$ TLCA は 0 $\mu \mathrm{mol} / l, 0.04 \pm 0.1 \mu \mathrm{mol} / l$ であった. GCDCA におい て胆管炎症例は非炎症例に比べ有意に高值を示した。 その他の胆汁酸分画においては群間に有意差を認めな かった。

b) 胆管炎と胆管内胆汁中の抱合胆汁酸（図 4)

GUDCA は非炎症例 $604.68 \pm 563.55 \mu \mathrm{mol} / l$ に対し 炎症例76.12 $\pm 96.8 \mu \mathrm{mol} / l$ であり, 以下各胆汁酸分画 は同様飞GCA $3,650.77 \pm 1,918.96 \mu \mathrm{mol} / l$, $1,193.43 \pm 1,357.49 \mu \mathrm{mol} / l$, GCDCA $4,043.99 \pm$ $2,331.80 \mu \mathrm{mol} / l, 1,299.58 \pm 1,670.65 \mu \mathrm{mol} / l, \mathrm{GDCA}$ $984.79 \pm 1,269.97 \mu \mathrm{mol} / l, 653.59 \pm 1,478.34 \mu \mathrm{mol} / l$, GLCA $57.16 \pm 110.24 \mu \mathrm{mol} / l, 90.16 \pm 218.27 \mu \mathrm{mol} / l$, TUDCA $75.53 \pm 47.39 \mu \mathrm{mol} / l, 10.9 \pm 20.36 \mu \mathrm{mol} / l$, TCA $1,453.46 \pm 1,331.96 \mu \mathrm{mol} / l, 924.97 \pm 1,463.86$ $\mu \mathrm{mol} / l$, TCDCA $1,574.53 \pm 976.35 \mu \mathrm{mol} / l$, $1,034.33 \pm 1,672.69 \mu \mathrm{mol} / l$, TDCA $332.83 \pm 522.1$ $\mu \mathrm{mol} / l, 8.88 \pm 23.51 \mu \mathrm{mol} / l$, TLCA trace, trace で あった. GUDCA, GCA, GCDCA およびTUDCA にお いて炎症例では非炎症例に比べ有意に低値を示した。

胆汁中細菌と抱合胆汁酸

各種腸内細菌による抱合胆汁酸の脱抱合4)5)㧊よび 一次胆汁酸の二次胆汁酸への変換が報告6)されてい る.そこで胆汁中細菌と抱合胆汁酸の関保につき検討

\section{図 4 総胆管結石症に招ける胆管胆汁中抱合胆汁酸}

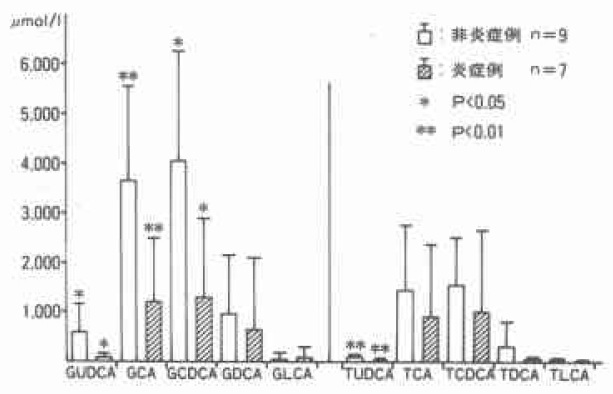

した.

a) 胆汁中細菌之胆管内胆汁中の抱合胆汁酸（图 5) (非炎症胆の5結石症例)

炎症による胆汁酸への影響を除外するため，非炎症 胆のう結石症例において胆汁中細菌之胆管内胆汁中の 抱合胆汁酸との関保につき検討した. 図 5 のごとく各 胆汁酸分画において胆汁中細菌の有無による有意差は 認められなかった。

b）総胆管結石症例 (非炎症例) に招ける胆汁中細菌 と胆管内胆汁中の抱合胆汁酸 (图 6)

胆管炎の無い総胆管結石症例において胆汁中細菌と 胆管内胆汁中の抱合胆汁酸との関係につき検討した。 各胆汁酸分画において群間に有意差を認めない.

総胆管結石症に扣ける胆管内胆汁中の胆汁酸濃度 (mol\%)（表 1)

総胆管結石症例におりる胆管内胆汁中の胆汁酸濃度 を $\mathrm{mol} \%$ で表示し胆汁中細菌の有無, 炎症の有無によ り群別し比較検討した，各胆汁酸分画において群間に

図 5 胆管内胆计中抱合胆汁酸と胆汁中細菌との夙係 （非炎症胆のう結石症例）

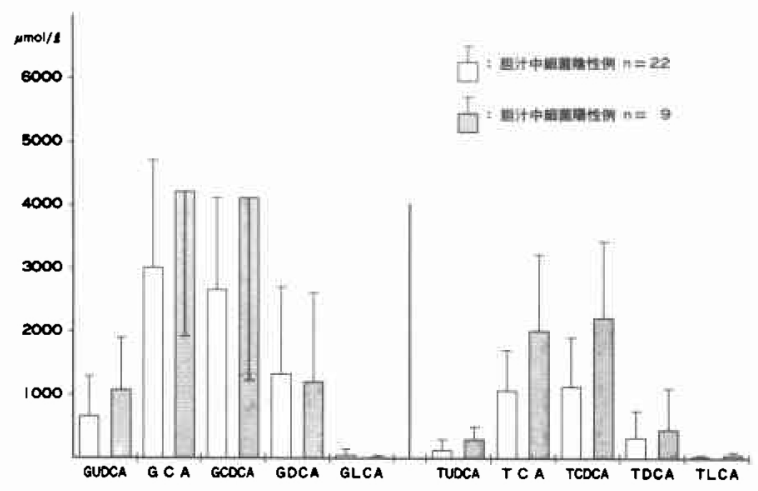

図 6 胆管内胆汁中抱合胆汁酸之胆汁中細菌之の成係 （非炎症総胆管結石症例）

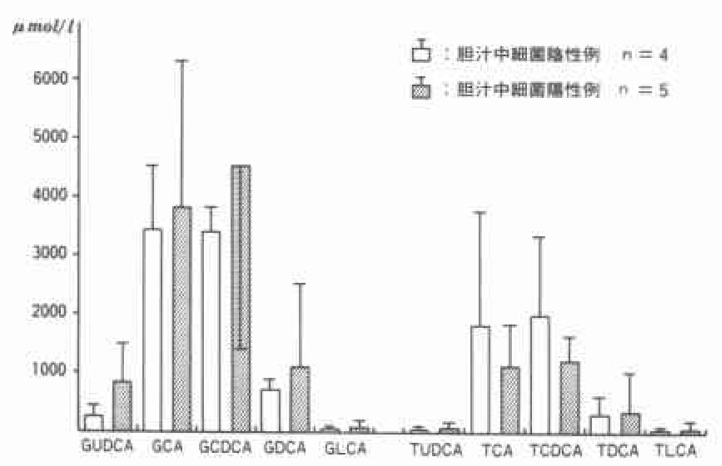


表 1 総胆管結石症における胆管内各胆汁酸濃度

\begin{tabular}{|c|c|c|c|c|c|}
\hline & & & & & $101 \%)$ \\
\hline & UDCA & $\mathrm{CA}$ & CDCA & DCA & LCA \\
\hline $\begin{array}{c}\text { 細菌( }+ \text { ( ) } \\
n=5\end{array}$ & $7.4 \pm 3.3^{*}$ & $37.3 \pm 4.8$ & $45.3 \pm 13.1$ & $9.1 \pm 13.3$ & $1.0 \pm 2.1$ \\
\hline $\begin{array}{c}\text { 細菌 }(-) \\
\mathrm{n}=4\end{array}$ & $3.0 \pm 1.7^{*}$ & $42.2 \pm 11.9$ & $44.8 \pm 2.3$ & $9.7 \pm 12.2$ & $0.4 \pm 0.7$ \\
\hline $\begin{array}{c}\text { 焱症 }(+) \\
\mathrm{n}=6\end{array}$ & $2.9 \pm 2.7$ & $50.7 \pm 18.9$ & $37.4 \pm 6.9$ & $8.2 \pm 14.6$ & $0.8 \pm 2$ \\
\hline $\begin{array}{c}\text { 资症 }(-) \\
\mathrm{n}=9\end{array}$ & $5.4 \pm 3.4$ & $39.5 \pm 8.46$ & $45.0 \pm 9.3$ & $9.4 \pm 12.0$ & $0.7 \pm 1.6$ \\
\hline
\end{tabular}

有意差は認められなかった。

胆石の性状と胆汁酸

胆汁の流出障害がなく胆のう炎が無い胆のう結石症 例につき赤外線スペクトル（コ系石：コレステロール $70 \%$ 以上, ビ系石：ビリルビン $30 \%$ 以上）および割面 の性状から判定したコ系石怙よびビ系石症例のみにつ いて胆汁酸分画を比較検討した。

a) 胆石と血中抱合胆汁酸 (図 7)

GUDCA はコ系石群で $0.98 \pm 1.65 \mu \mathrm{mol} / l$, ビ系石群 $1.83 \pm 2 \mu \mathrm{mol} / l$ である.以下同様に各胆汁酸のコ系 石，ビ結石群に打ける濃度は，それそれ GCA $3.98 \pm$ $7.48 \mu \mathrm{mol} / l, 6.24 \pm 8.11 \mu \mathrm{mol} / l$, GCDCA $3.18 \pm 4.7$ $\mu \mathrm{mol} / l, \quad 6.66 \pm 8.26 \mu \mathrm{mol} / l$, GDCA $0.58 \pm 1.27$ $\mu \mathrm{mol} / l, 0.87 \pm 0.42 \mu \mathrm{mol} / l$, GLCA $0.02 \pm 0.14 \mu \mathrm{mol} /$ $l$, trace, TUDCA $0.06 \pm 0.12 \mu \mathrm{mol} / l, 0.18 \pm 0.1$ $\mu \mathrm{mol} / l$, TCA $0.7 \pm 1.98 \mu \mathrm{mol} / l, 1.77 \pm 2.45 \mu \mathrm{mol} / l$, TCDCA $\quad 0.58 \pm 1.08 \mu \mathrm{mol} / l, \quad 2.93 \pm 3.79 \mu \mathrm{mol} / l$, TDCA $\quad 0.02 \pm 0.06 \mu \mathrm{mol} / l, \quad 3.05 \pm 4.91 \mu \mathrm{mol} / l$, TLCA trace, $0.06 \pm 0.1 \mu \mathrm{mol} / l$ であった. 各胆汁酸に 扣いて結石別の有意差は認めなかった。

図 7 胆のう結石症例（非炎症）に括ける血中抱合胆 汁酸

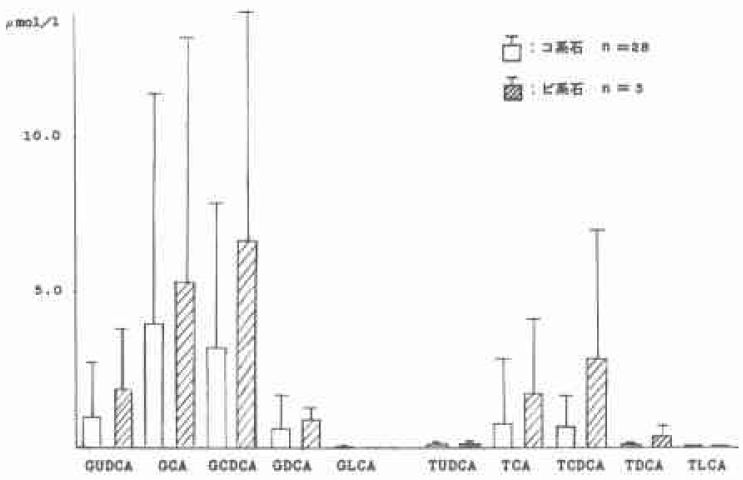

図 8 胆の5結石症例（非炎症）の胆管内胆汁中抱合 胆汁酸

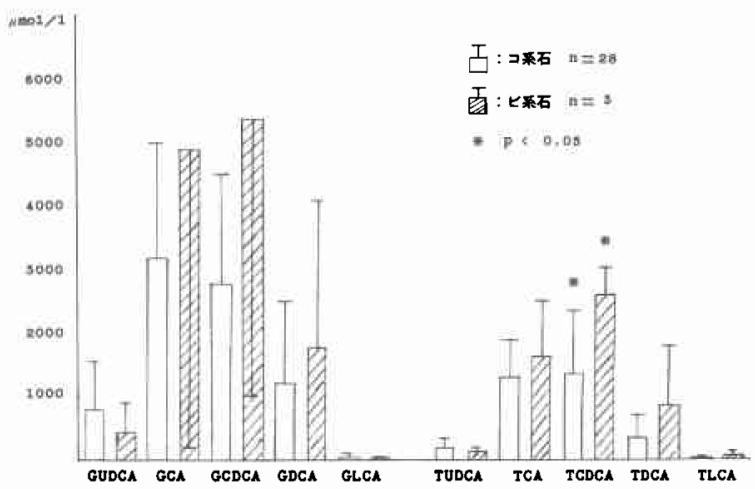

b) 胆石と胆管内胆汁中の抱合胆汁酸（図 8)

资症のない胆のう胆石症例において結石と胆管内胆 汁中の抱合胆汁酸との関係を検討した. GUDCA はコ 系石828.6 $\pm 787.53 \mu \mathrm{mol} / l$, ビ系石 $494.86 \pm 462.36$ $\mu \mathrm{mol} / l$ であった. 以下, 各胆汁酸分画は同様に, GCA $3,198.11 \pm 1,788.37 \mu \mathrm{mol} / l, \quad 4,915.72 \pm 4,789.46$ $\mu \mathrm{mol} / l$, GCDCA $2,852.03 \pm 1,682.45 \mu \mathrm{mol} / l$, $5,361.98 \pm 4,337.19 \mu \mathrm{mol} / l$, GDCA $1,269.11 \pm$ $1,293.32 \mu \mathrm{mol} / l, 1,744.86 \pm 2,217.31 \mu \mathrm{mol} / l$, GLCA $36.33 \pm 89.33 \mu \mathrm{mol} / l, 19.7 \pm 34.11 \mu \mathrm{mol} / l$, TUDCA $193.89 \pm 218.70 \mu \mathrm{mol} / l, 115.07 \pm 97.96 \mu \mathrm{mol} / l, \mathrm{TCA}$ $1,303.32 \pm 1,055.44 \mu \mathrm{mol} / l, 1,660.76 \pm 661.46 \mu \mathrm{mol} /$ l. TCDCA $1,351.56 \pm 1,090.94 \mu \mathrm{mol} / l, 2,383.97 \pm$ $476.49 \mu \mathrm{mol} / l$, TDCA $348.26 \pm 374.23 \mu \mathrm{mol} / l$, $855.87 \pm 1,047.46 \mu \mathrm{mol} / l$, TLCA $17.49 \pm 36.44$ $\mu \mathrm{mol} / l, 51.16 \pm 78.01 \mu \mathrm{mol} / l$ であった. TCDCA に おいてコ系石症例でビ系石症例に比べ有意に低值と なった。

胆石症と胆汁酸との関係については古くから多くの 研究17) 9)がなされているが, 従来の測定方法では血中 などの微量胆汁酸を検出できないものが多い。近年， 微量の血中胆汁酸測定にもHPLCをはじめ種々の測 定法2)310111)が開発されている. Kanazawa ら ${ }^{12)}$ は従 来，胆汁酸分析に頻用されていたガスクロマトグラ フィーはいくつかの理由で HPLCより劣ると指摘し ている.

今回, われわれは奥山法に準じ2), 約10ng まで測定可 能な $3 \boldsymbol{\alpha}$-HSD 固定化䤃素カラムを使用した HPLCを 使用し，コレステロール結石症例括よびビリルビンカ ルシュウム結石症例のみを対象とし血中および胆管内 
胆汁の測定を行い, 胆石, 胆汁中細菌, 胆道系炎症之 の関係を比較検討した.

胆汁の流出障害が無く炎症が無いと判定された胆の う結石症例において，結石別に比較検討すると血中胆 汁酸では差が無く，胆管胆汁ではコ系石症例において 有意に TCDCA が低値を示した。コレステロール結石 症例に括いて Danzinger ら ${ }^{13}$ は CDCAによる胆石溶

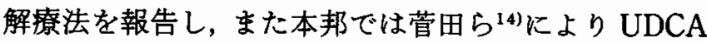
による胆石溶解療法が報告され，以後両胆石溶解剂の 有効性が多数報告されている．われわれのこの成積か らみると減少している胆汁中の TCDCA を増加させ るという意味でCDCA 投与の有効性があるように思 われる. 一方, 胆石溶解剤の胆石溶解機点としては, 胆汁酸プールを増加させることによるとする報 告15)16), 胆汁中コレステロール排泄の减少にともなう lithogenic index を改善させると指摘する報告 ${ }^{15)}$, コ レステロール合成律速酵素 HMG-CoA reductase の 活性を低下させることにより胆汁中コレステロールが

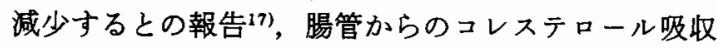
障害によるとする報告 ${ }^{18)}$, CDCA 投与によりコレステ ロールのミセル化が促進するとの報告 ${ }^{19)}$, UDCAによ

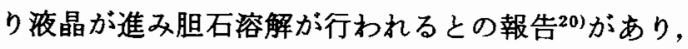
また，それらの反対の報告もあり一定した見解が得ら れていない.

一方, Maruyama ${ }^{21}$ は胆のう胆汁中の胆汁酸に拈い てビ系石症例で GCDCA の低下を報告しているが，わ れわれの胆管胆汁中の成績では, コ系石症例とビ系石 症例との間に GCDCA の差を認めなかった. 今後, 胆 のう胆汁と胆管胆汁との胆汁酸分画の差があるのか,

どらかを含めさらに検討されるべきと考兄られる。

胆汁中細菌と胆汁酸との関係についてみると胆汁の 流れが良好な胆のう結石症例においても, 胆汁流出障 害がある程度想定される総胆管結石症例に颃いても， 胆汁中細菌の有無による胆管内胆汁酸組成の差は見ら れなかった，in vitroに颃いて嫌気性菌をはじめとす る腸内細菌の抱合胆汁酸の脱抱合能45), 一次胆汁酸か ら二次胆汁酸への変換胡が報告されているが，われわ れの臨床成續では，急性化膿性胆管资のごとき著明な 胆汁流出障害が無ければ，胆管胆汁酸への細菌による 影響は少ないと考えられた。しかし，急性化膿性胆管 资では胆汁酸変換に関与する嫌気性菌が高率に好気性 菌と混合で分離されて ${ }^{22}$ 打り, 起炎性のある二次胆汁 酸, 遊離胆汁酸が問題となる可能性は否定できない。 胆道系炎症の有無と胆汁酸との関係を検討すると,
胆のう結石症例では胆のらの炎症の有無による血中抱 合胆汁酸の变化は無かったが, 胆管内胆汁中の抱合胆 汁酸は二次胆汁酸である GDCA, GLCA のみが炎症例 で低下していた，このことは炎症例では血中胆汁酸の 変化が無いにもかかわらず胆汁中の GDCA, GLCA が 低下して括り，腸肝循環のどこかで GDCA，GLCA が 吸収むしくは喪失したと考えられ，その場として炎症 のある胆汁酸プールの場として小腸とならぶ胆のうを 考えたい. Dietschy ${ }^{23}$ によれば炎症があると胆のう上 皮の吸収能は充進すると述べて括り，われわれの推論 を説明するには都合の良い報告である，胆汁の流出障 害が考えられる総胆管結石症例の血中胆汁酸について みると, 胆管炎症例の GCDCA が非炎症例に比べ有意 に高値となった。 また，血中 GCA, TCA, TCDCA は 有意差は無かったが胆管炎症例において異常高値例が 認められた。胆管内胆汁の抱合胆汁酸については胆管 炎で GUDCA, GCA, GCDCA, TUDCA の低下が認め られた。 上野山 ${ }^{24)}$ 同様に HPLC 法にて血中胆汁酸を 測定し, 慢性肝障害症例 GCDCA が高値となると報告 し，われわれと同様の成績を得ている。一般に血中胆 汁酸上昇の機序として, 腸管より再吸収されて肝細胞 に撕取される際, 肝細胞膜障害によりそのまま大循環 系へ流れる可能性, 肝細胞癌に取り込まれた胆汁酸の 輸送機構の破綻に上る血中への逆流の可能性, 肝内 shunt の形成による血中移行の可能性. Disse 腔などの 破綻にともな5 cholangio-venous reflux の可能性な どが文献的に論じられている ${ }^{1011)}$ ，われわれの成績で は胆管炎症例に怙いて, 血中二次胆汁酸は变化しない ことから胆管炎症例に招ける血中胆汁酸上昇機構とし て, Disse 腔の破綻などの肝の器質的異常が招来され た可能性が示唆される。

胆管炎症例に执いて胆管内 GCA, GCDCA の低下が 認められる点について考案するに, 血中ではグリシン 抱合型一次胆汁酸 GCDCA の上昇を認めるのでグリ シン抱合能はそれ程障害は無く, また, 肝障害の主体 は, 胆管内 TCA, TCDCA には変化がないので一次胆 汁酸のグリシン抱合後の排泄経路における障害の結果 であると推論された。 なお，Jacobson ら ${ }^{25}$ はグリシン 抱合能はタウリン抱合能に比べ種々の因子の影響をう け易いと述べている.一方, Vlahcevic ら》によれば, 胆石症例では胆汁酸プールが正常人の半分に減少して

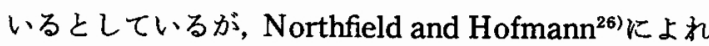
ば胆汁酸ブールの大きさと腸肝循環の頻度すは逆相関 にあり, 胆石症患者では胆汁酸プールが減少している 
にすかかわらず腸肝循環回数の増加により胆汁酸分泌 はほとんど变化しないとしている，また，胆汁酸の生 成は, 肝細胞内に流入する胆汁酸量によってフィード

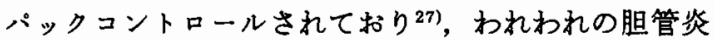
症例に扮いても肝障害にとすなう CA, CDCA の合成 障害は少ないと考えられた。

UDCAの代謝経路として Mahowald ${ }^{28)}$, Samuelsson ${ }^{29)}$ が腸管内に拈いて CDCA か LCA 一変換され，ついで肝臓において7-keto LCA か ら UDCA へ変換されることをラットの実験で推論し ている. また, Salen ら ${ }^{30}$ 梳胆石症患者 4 例および Cerebrotendinous Xanthomatosis 3 例にCDCA 4 カ 月投与したところ胆汁中の UDCA の増量が認めら れ，また ${ }^{3} \mathrm{H}$ 標識 CDCA の静注後の胆汁中 UDCA 分 画への放射能の出現状況や ${ }^{3} \mathrm{H}$ 標識7-keto LCA 由来 の放射能が UDCA, CDCA 両分画に検出されることか ら, 前記ラットの実験と同様に人に括いても CDCA $\rightarrow$ 7-keto LCA $\rightarrow$ UDCA の合成系が肝で行われている と推論している。われわれの胆管资症例では二次胆汁 酸が非炎症例と差が無いにもかかわらず GUDCA TUDCA は低値となり，胆管炎にともなう肝障害によ りUDCA 合成が低下したものと考えられ，UDCA 合 成に肝が関与するのは間違い無いるのと考えられる。

われわれが検討を行った胆管炎症例には重症な急性 化膿性胆管炎症例は含まれておらず，術前に急性胆管 炎と判定され抗生物質投与などの保存的療法で臨床的 に治瘙したと判定された後，手術を施行した症例であ る. 胆管炎の既往のある胆石症例では臨床的に異常が 認められなくても，血中および胆管内胆汁酸をみるか ぎり肝細胞障害が存在すると考えられる，かかる症例 に対しては肝障害の進行しない前に, 胆石症の手術に よる胆汁らっ滞の原因除去を行うことが肝要であり， また過大な手術侵㜔や出血などにより予期せざる肝障 害の悪化，肝不全などを惹起する可能性のあることを 十分念頭に括いて，細心な注意と肝庇護対策が必要で あると考える。

\section{結 語}

1）総胆管結石症例において，胆管炎をともなうすの では资症のないものに比べ血中 GCDCA の上昇, 胆管 胆汁中の GCA, GCDCA, GUDCA, TUDCA の低下が あり, 胆汁らっ滞性肝障害にともならグリシン抱合型 一次胆汁酸の排泄障害, 肝におけり UDCA 合成抑制, 肝に括ける器質的破糘の可能性が示唆された。

2）胆汁の流出障害がなければ, 胆汁中に存在する細
菌が胆汁酸組成に影響をおよばすことは少ない。

3）胆のう結石症例において,ビ系石症例に比べコ系 石症例で胆管内胆汁中の TCDCA が低下していた。 本文の要旨の一部は第23回，日本消化器外科学会におい て発表した。

\section{文献}

1) Admirand WH, Small DM: The physicochemical basis of cholesterol gall stone formation in man. J Clin Invest $47: 1043-1052,1968$

2）奥山澄彦：高速液体クロマトクララフィーに固定化 酵妻カラムを組み合せた血中遊離および抱合型各 胆汁酸分画の高感度鉴光分析測定。肝臓 20 ： 1194,1979

3）馬場茂明，住八江啓子，上野山林造ほか：高速液体 クロマトクラフィーによる血中胆计酸分画の高感 度喾光分析測定法。医と生物 $97: 219-223,1978$

4) Aries V, Hill MJ : Degradation of steroids by intestinal bacteria. I. Deconjugation of bile salts. Biochim Biophys Acta $202: 526-534$, 1970

5) Shimada K, Bricknell KS, Finegold SM : Deconjugation of bile acids by intestinal bacteria. Review of literature and additional studies. J Infect Dis 119 : 273-281, 1969

6) Hill MJ, Draser BS : Degradation of bile salts by human intestinal bacteria. Gut $9: 22-27$, 1968

7) Vlahcevic ZR, Bell CC, Buhac I et al: Diminished bile acid pool size in patients with gallstones. Gastroenterology $59: 165-173,1970$

8) Nakayama F, van der Willem L: Bile from gallbladder harbouring gallstone: Can it indicate stone formation? Acta Chir Scand 136 : $605-610,1970$

9）大久保尚男：ガスクロマトクララフィーによる胆汁 中䏣汁酸の臨床的研究. 日外会誌 $67: 865-885$, 1968

10) Makino I, Nakagawa $S$, Mashimo $K$ : Conjugated and unconjugated serum bile acid levels in patients with hepatobiliary diseases. Gastroenterology $56: 1033-1039,1969$

11）大营俊明, 桌重文子, 今井一洋ほか：血中胆汁酸測 定とその意義。内科 $37: 1351-1355,1976$

12) Kanazawa $Y$, Koizumi $M$, Hirakawa $h$ et al: Effect of UDCA on biliary acid composition in patients with cholesterol gallstone. Tohoku J Exp Med 136 : 235-249, 1982

13) Danzinger RG: Dissolution of cholesterol gallstones by chenodeoxycholic acid. New Engl J Med 286:1-8, 1972

14）菅田文夫，清水盈行：胆石陰影消失例の再検討。日 
消病会誌 $71: 75-84,1974$

15) LaRusso NF, Hoffman NE, Hofmann AF et al: Effect of primary bile acid ingestion on bile acid metabolism and biliary lipid secretion in gallstone patients. Gastroenterology 69 : 1301-1314, 1975

16) Von Bergmann $K$, Gutsfeld M, Schlze-Hagen $K$ et al: Effect of ursodeoxycholic acid on biliary lipid secretion in patients with radiolucent gallstones. Biological effects of bile acids (ed. by Paumgartner), G.9, MTP, Lancaster, 1979, 61-66

17) Maton PN, Murphy GM, Dowling RH: Ursodeoxycholic acid treatment of gallstones. Lancet 2: 1297-1301, 1977

18) Pons de Leon M, Carulli N, Loria $P$ et al: The effect of chenodeoxycholic acid (CDCA) on cholesterol absorption. Gastroenterology 77 : 223-230, 1979

19) Corrigan OI, Su CC, Hignchi WL et al: Mesophase formation during cholesterol dissolution in ursodeoxycholate-lecithin solution; new mechanism for gallstone dissolution in human . J Pharm Sci $69: 869-871,1980$

20) Igimi $H$, Asakawa $S$, Watanabe $D$ et al: Liquid crystal formation in ursodeoxycholaterich human bile. Gastroenterologia Japonica $18: 93-97,1983$

21) Maruyama $\mathrm{K}$ : Analysis of conjugated bile acids in bile by high pressure liquid chromatography. II. Clinical application in bile of patients with gallstones. Arch Jpn Chir 51 : 14-43, 1982

22）花井拓美, 由良二郎, 品川長夫：急性化膿性胆管炎
についての細菌学的考察一特に嫌気性菌との関保 について一. 日消外会誌 $15: 774-780,1982$

23) Dietschy JM : Recent developments in solute and water transport across the gall bladder epithelium. Gastroenterology $50: 692-707$, 1966

24）上野山林造：血中胆汁酸分画の臨床的意義に関す る研究. 第 2 編. 肝胆道系疾患診断における血中胆 汁酸分画の意義。神戸医学紀要 $42 ： 499-507$, 1980

25) Jacobsen JG, Smith LH Jr : Biochemistry and physiology of taurine and taurine derivatives. Physiol Rev 48 : 424-511, 1968

26) Northfield TC, Hofmann AF: Biliary lipid secretion in gallstone patients. Lancet 1 : 747-748, 1973

27) Dowling RH, Mack E, Small DM: Effects of controlled interruption of the enterohepatic circulation of bile salts by biliary diversion and by ileal resection on bile salt resection. Synthesis and pool size in the rhesus monkey. J Clin Invest $49: 232-242,1970$

28) Mahowald TA, Matschiner JT, Hsia SL et al : Bile acids. VII. Metabolism of 7-ketolithocholic acid-24-14C in the rat. J Biol Chem 230 : 581-586, 1958

29) Samuelsson B : The metabolism of 7-ketolithocholic acid-24-14C in the rat. Acta Chem Scand 13:236-240, 1959

30) Salen G, Tint GS, Eliav B et al: Increased formation of ursodeoxycholic acid in patients treated with chenodeoxycholic acid. J Clin Invest $53: 612-621,1974$ 